\title{
The Role of Cultural Values in Motivating the Competencies of Hindu Balinese Human Resources in Tourism to Gain Manager Level Positions in Rated Hotels in Bali
}

\author{
Sulistyawati \\ Doctorate Program in Tourism \\ Universitas Udayana
}

Corresponding author: prof.sulistyawati@yahoo.com

\section{ARTICLE INFO \\ Received \\ 20 March 2016 \\ Accepted \\ 30 August 2016 \\ Available online 15 September 2016}

\section{ABSTRACT}

In response to the new era of the ASEAN Economic Community (AEC) since year 2015 - Bali, as the primary gateway of Indonesian tourism, must improve the quality of Hindu Balinese human resources in tourism (HB HRT). Winata (2014: 6) explained that adat istiadat (customs and traditions) is one of the cause for their low commitment in their job, as HB HRT often take leave due to adat obligations. Therefore, one of the impact, as in the case of a hotel in Kuta, is that hotels often avoid recruiting HB HRT. Hence, issue to be discussed in this study is to understand the role of Balinese Cultural Values as a potential and as an obstacle in HBHRT's competency to achieve managerial positions in star-rated hotels in Bali. The research will use a concurrent triangulation method on data collected through interviews and questionaires. While sampling will be done with Purposive Sampling method on star-rated hotels located in Sanur, Kuta and Nusa Dua. Finally, the data analysis will be carried out by referring to Motivation Theory (McClelland, 1976), Competency Theory (Spencer and Spencer, 1993), Value Orientations Theory (Kluckhohn and Strodtbeck, 1961), through a descriptive interpretative qualitative approach as well as a quantitative approach based on Principal Component Analysis (PCA) statistics.

The research results will show that based on the data, HB HRT have good set of competencies, and these good competencies are inseparable from their background of Balinese Cultural Values (BCV), mainly derived from Hindu culture and religion. As part of upholding their culture, a HB HRT is a person with pawongan concept of harmonious relationship between human beings indicated by $79.1 \%$ people with tresna (love), the parhyangan concept of harmonious relationship between human beings and God indicated by $75 \%$ people engaging in dharma yatra pilgrimages and study, and the palemahan concept of harmonious relationship between human beings and nature indicated by $69.8 \%$ people valuing Bali shanti (a peaceful Bali). On the other hand the obstacles in occupying manager positions in starrated hotels in Bali are mostly due to internal factors - namely, their own personal motives which are often based on erroneous understandings of BCV. Therefore, in order to increase the Spiritual 
Quotient (SQ) of HB HRT in achieving managerial positions, the strategy will be through career development with motivation programs while redefining their Balinese Cultural Values to give positive impact to their living standard, to the company, to the environment, and to God.

Keywords: hindu human resources, motivation, manager position, rated hotels, bali

\section{Introduction}

Bali, as the primary gateway of Indonesian tourism, is growing rapidly. This rapid development of tourism on the island has become a magnet for job seekers from local, from other Indonesia provinces, and even from overseas, who have their eyes set on strategic positions in Bali tourism industry. The activation of the ASEAN Economic Community (AEC) has imposed greater challenge in Tourism Human Resources market for balinese. In facing this challenge, Bali must improve the quality of its Hindu Balinese Tourism Human Resources (HB HRT). Therefore, strengthening the competencies of HB HRT is a prioritiy in order to increase their competiveness. Competencies must be mastered by HB HRT if they aspire to compete for top manager positions in star-rated hotels in Bali.

This is certainly an irony for Bali tourism given the fact that the majority of hotels in Bali employ foreign human resources for the top manager positions. The reason is mainly because foreign HR has proven record of their competencies and because they have stronger commitment than HB HRT. Hence, hotels prefer foreign tourism HR for manager positions rather than HB HRT. According to Spencer and Spencer (1993:9), competent people are those who possess motives, knowledge, skills, a self-concept, and traits in accordance with the job requirements to actively participate in the work place.

In respond to the increasing number of foreign workers occupying strategic positions in Bali tourism industry, Balinese people must dare to undergo a change of mindset about their customary and religious practices and make greater effort to improve the competencies of HB HRT. Hindu Balinese tourism human resources must play an active role to become leaders or managers, so that they do not merely occupy operational level positions without having any share in the decision-making process of a company. For this, HB HRT are required to have strong motivation for achievement in order to compete for a strategic role in the company where they work.

Motivation is a very important aspect for HB HRT because with strong motivation for achievement they can reach higher level of productivity and can demonstrate their accomplishments to be able to compete in obtaining a strategic position in the company; namely a top manager post in a star-rated hotel in Bali. Given the above, this study will further explore The Role of Cultural Values in shaping the Competencies of Hindu Balinese Tourism Human Resources to achieve Manager Level Positions in Star-Rated Hotels in Bali. Specifically, as described in the introduction and based on theoretical and empirical ideas, this paper will explore and explain about the role of Balinese Cultural Values as a potential and as an obstacle in HBHRT's competency to achieve managerial positions in star-rated hotels in Bali.

\section{Literature Review}

A simple fundamental understanding of competency is an ability or adroitness (Syah, 2000: 229). Spencer and Spencer (1993: 9-11) suggested that there are five types of competency characteristics, which are: (a) motives; (b) traits; (c) self-concept; (d) knowledge, and (e) skills. Pelly (1994: 1) added that each human resource should 
possess competencies - these being abilities or adroitness which illustrates a person's qualifications or capabilities. Motivation is an important force for a person to improve their competence. Motivation originates from the Latin word movere meaning an impulse, desire, cause, or reason for someone to do something. According to Manullang 1982:150), motivation provides employees passion to work; in other words, it stimulates human resources to optimize their competencies. McClelland (1976, see also Robbins, 2001: 173) put forth Achievement Motivation Theory which asserts that human beings essentially have an ability to excel beyond others. This theory has an assumption that the need for achievement is different and is distinguishable from other types of needs. According to McCelland, there are three types of human needs, which are the need for achievement, need for power, and need for affiliation.

There are a number of cultural values in the human society which are interrelated in such a way that they appear as a system. This system is a guideline for the ideal concept of any culture which influences the direction and orientation of community living. Anthropology experts, Kluckhohn and Strodtbeck (1961) explained that any culture consists of five basic human problems for determining value orientations, namely: 1) the character of human nature; 2) human beings relationship to the nature environment; 3) human beings sense of space and time; 4) the modality of human activity; and 5) the nature of human beings relationship to other people.

\section{Methodology}

A concurrent triangulation design will be used to collect both qualitative and quantitative data through in-depth interviews with twenty-three informants and distribution of questionnaires to 182 respondents. All results will be analyzed with descriptive interpretative method through Principal Component Analysis (PCA) statistics.

The data sampling with purposive sampling technique on informant and sample selections have lead to: three, four, or five-star hotels that are strategically located in dense tourism areas and easily accessible. The sampling location will limited to three wellknown tourist areas in Bali, which are Sanur in the Denpasar municipality as well as Kuta and Nusa Dua in the Badung regency.

The role of Balinese Cultural Values as a potential and as an obstacle in HBHRT's competency to achieve managerial positions in star-rated hotels in Bali

HB HRT have good competencies. Results from the interviews conducted with twentythree informants occupying managerial positions in star-rated hotels in Bali, based on the five types of competency characteristics according to Spencer and Spencer, (1993: 911), show that more than $50 \%$ agree that $\mathrm{HB}$ HRT are competent in their self-concept, knowledge, and skills. These three competency characteristics are considered the key sets of competences for managerial positions. Therefore, HB HRT are supposed to be able to occupy manager positions in starrated hotels in Bali.

The good competencies that HB HRT possess are inseparable from their Balinese Cultural Values derived from Bali Hindu cultural and religious concepts. Result of the quantitative analysis about HB HRT based on cultural variables, shows that most HB HRT firmly uphold the pawongan concept of harmonious relationship between human beings evidenced by a weight factor of $94.3 \%$. This is followed by a $92.6 \%$ weight factor for the parhyangan concept of harmonious relationship between human beings and God and then an $87.9 \%$ factor for the palemahan concept of harmonious relationship between human beings and nature. HB HRT tend to care most for pawongan - harmonious relationships between human beings indicated by $79.1 \%$ agreeing to the importance of tresna (love) and always serving with smile.

The second strongest cultural value for HB HRT is parhyangan - the harmonious relationship between human beings and God indicated by $75 \%$ engaging in dharma yatra pilgrimages and study of nature. HB HRT selfconcept always adheres to dharma yatra or value of integrity. By upholding such value, HB HRT completely avoid any dishonesty in competition to achieve successful career, rather, they believe that learning to advance 
their knowledge to achieve such success is a form of worships to God. The third strongest cultural variable for HB HRT is palemahan the harmonious relationship between human beings and nature, indicated by $69.8 \%$ valuing Bali shanti (a peaceful Bali). This is evidenced by high HB HRT preference for peaceful work environment where all people feel calm and happy to complete their respective tasks without conflicts, or in simple term, Bali shanti (a peaceful Bali), which eventually affects HB HRT's motivation. So, based on the description of these cultural variables, a HB HRT is a person who feels tresna (love), shows friendliness, engages in dharma yatralikes to study, and aspires to create Bali shanti (a peaceful Bali). These Balinese Cultural Values influences HB HRT's competencies to be good and distinctive, making it an outstanding quality of HB HRT to able to occupy the position of manager in star-rated hotels in Bali.

However, there are still some HB HRT that have a different way of understanding and application of Balinese cultural values, fundamentally affects their competency and impedes their work performance, stopping them in achieving managerial positions in their work place. This is mostly influenced from the physical, social, cultural, and educational environment of their place of origin during their childhood as well as the low exposure of the economies of tourism industry. These factors cause differences in the orientation toward cultural values, which affects their approach of decision-making. These variations in the orientation toward cultural values of HB HRT can be classified into three types: immutable, transitional, or mutable in relation to the five basic problems of human beings according to the theory of Kluckhohn and Strodtbeck (1961) described as follows:

1. The first problem concerning the character of human nature of HB HRT

In some cases there are some HB HRT who are influenced by conservative cultural values karma phala, punarbhawa (reincarnation) and the tembang song phrase of ede ngaden awak bisa, depang anake ngadanin - meaning one should always be humble in this life, a misunderstanding about the cultural values which influence attitudes and insights of decision-making process in their work. This misunderstanding leads to the perception that life is bad (conservative), work only adds to a series of reincarnation (Punarbawa / samsara) and the power as a leader can prevent one from achieving nirvana, so that the tembang song phrase of ede ngaden awak bisa is interpreted as there is no need for competition. This interpretation translates to HB HRT having humble personality, not showing off despite of having good leadership skills, and not participating in the competition to occupy the manager position. This nocompetion and no-show off value indicator have popular response from HB HRT with a weight value $68 \%$. However, there are some HB HRT who have the understanding that life is bad but can transform into good karma (cultural transition), so they have the motivation and passion in working to improve the economic conditions. Strong response to indicators to do good job and work optimally got a weight value of $70.7 \%$, as well as indicators of doing work with all the ability has weight value of $64.5 \%$. There are also many HB HRT that interpret that this life is good (cultural progressive), need to work enthusiastically with high creativity to perform well, to improve their skills, and have high innovating initiative in their profession. Indicators of the ability to create and innovate have a strong response with a weight value $82.80 \%$.

2. The second problem concerning the relationship of human beings to the nature and environment

HB HRT believe that nature is magnificent, an essential proof of God's Power and Grace in which human must submit to and respect (conservative culture), this is seen from the strong response to indicators of dharma yatra culture (pilgrimage and learn from nature) with a weight of $75 \%$. Some HB HRT like to seek harmony from the nature (transition), so they strongly respond to cultural concepts of karma phala with a weight of $73.7 \%$ and Asih (feeling of love towards nature) with a weight of $68.9 \%$. However, there are also HB HRT who see nature as a mystery to be solved and to be ruled over as a gift from the God to mankind (progressive), by responding to the strong cultural concept of dharma karya with a 
weight of $73.4 \%$. These three point of views can be seen from the way HB HRT interact with his natural and work environment, in which one or more will be applied appropriately to create the working environment with local talent that is based on the concept of Tri Hita Karana.

3. The third problem concerning human beings sense of space and time

One of HB HRT's personalities is to uphold the importance of the ancient culture value (conservative) as an orientation with strong values of patience and persistence. These HB HRT with such personality are usually diligent workers who respond strongly to work with a smile (tresna) indicator with a weight of $79.1 \%$, work responsibly (cucud) indicator with a weight of $75 \%$, and the concept of ngayah culture with a weight of $56.9 \%$. On the other hand, some HB HRT focus on the present (transition) during their effort to achieve success, these people are usually very resilient in work, they respond strongly to the concept of jemet culture with a weight of $67.6 \%$. Some other HB HRT look far into the future (progressive), select personal progress as their achievement, diligently fulfilling themselves with adding insights through education and training. They strongly respond to three indicators: 1 . jengah culture (increasing knowledge, skills, experience and insight to advance) with a weight of $70.2 \%, 2$. karang awake tandurin culture (hone themselves) with a weight of $68.4 \%$, and 3. the cultural concept of dharma karya (work ethic and high creativity) with a weight value of $73.4 \%$.

4. The fourth problem concerning work and work productivity

Some of HB HRT are still very conservative in their view of work, for them it is merely an attempt for survival (survival), so they are less interested in hard work, evidenced by the lack of response to the indicator 'working for unmet needs' with weight of $45.2 \%$. But other HB HRT embrace transition culture who considers 'hard work to get status, position, accession of power as a measure of achievement', thus reaching the manager's position as a powerful symbol of high status. Can be seen from the strong response to the indicators of cucud culture

with a weight value of $75 \%$, the concept of karma phala with a weight of $73.7 \%$, and cultural concepts jemet $67.6 \%$. However, most HB HRT's orientation is progressive culture, working towards the highest achievement, work to produce work results, not the status, lacking care for the manager position (weak motivational power). But when given such managerial task, they will perform successfully (do not want the competition). Such HB HRT strongly responds to dharma karya culture (work ethic high creativity) indicated by $73.4 \%$ weight value.

5. The fifth problem concerning the nature of human relationship to others

Some of HB HRT who emphasize on the importance of vertical relationships prefer to refrain themselves from expressing their personal opinion (koh ngomong), seen from the strong response to indicators of de cara goake ngadanin iba culture- do not like to boast and the tembang song phrase ofede ngaden awak bisa, depang anake ngadaninmeaning that one should always be humble in this life with a weight of $74.1 \%$. But there are also some of HB HRT who prefer to emphasize on horizontal relationships (collateral) between individuals. Which can be seen from the strong response to the indicators of tat twam asi culture with a weight value of $74.1 \%$ followed asta brata culture with a weight value of $71.8 \%$ and supported by sagilik saguluk salulung sebayantaka culture (united either in safety or in danger) with a weight value of $71.5 \%$.

Another group of HB HRT believes in individual self-reliance, so their leadership style will be authoritarian. It relates to strong response of asta brata culture with a weight value of $71.8 \%$, followed by karang awake tandurin culture indicator (hone themselves) with a weight value of $68.4 \%$, and jemet culture with a weight of $67.6 \%$, while polos culture (honest and forthright) has a weight of $61.2 \%$. All of which coresponde to strong response of dharma karya culture (work ethic with high creativity) indicated by $73.4 \%$, and cultural concept of tri kaya parisudha (thoughts, words and actions that must be purified in order to be good and right) with a weight of $67.5 \%$. 


\section{Conclusions and Recommendations}

The conclusions of this study, indicates that HB HRT are equipped with good competences, they are capable of working and occupying managerial position at star-rated hotels in Bali. These good competences are inseparable from their BCV background which is derived from the concepts of Hindu Balinese culture with the accurate understanding and interpretation. With such unique qualities, most HB HRT has comparable competence and even superior in comparison to human resources from out of Bali, foreign or local. HB HRT's BCV will be able to improve CuQ and SQ as a stimulus for the growth of SoQ, AQ, CQ, and XQ that are based for HB HRT's LQ.

However, a wrong interpretation of the $\mathrm{BCV}$, specifically about leaders controlling power can translate to low $\mathrm{CuQ}$ and SQ about the importance of the manager's position for some HB HRT. A special strategy is required to convince HB HRT about the importance of manager positon for HB HRT by strengthening its $\mathrm{CuQ}$ and SQ. One approach is to give motivational programs for career development through internal development, such as programs to align the understanding of the role of leadership in their $\mathrm{BCV}$, as contributing factor towards the improvement of living standard, the company's betterment, and the surrounding environment, ultimately fulfilling God's mission for human beings.

Based on this conclusion, we can derive a general theory that with the five criteria of competence specified earlier, together with the accurate and positive understanding of the $\mathrm{BCV}$, there are prospective HB HRT for managerial positions who will continuously adapt and integrate Balinese culture value and Hindu religious value with the values of tourism, in the development paradigm of cultural tourism in Bali. With this theory, Bali will be able to produce HB HRT that has high $\mathrm{CuQ}$ and $\mathrm{SQ}$, broad-minded, and thoughtful to the dynamic needs of the Balinese Modern People, which will finally lead to new sets of intelligence as part of growing intelligence of leadership (LQ) HB HRT in the tourism field, especially star-rated hotels in Bali.

\section{References}

Kluckhohn, F. R. and Strodtbeck, F. L. (1961) Variation in Values Orientation:A Theory Tested in Five Culture. Evanston, Illinois: Row, Peterson and Co.

Manullang, M. (1982) Manajemen dan Personalia. Cetakan ketiga. Jakarta: Aksara Baru.

Pelly, U. (1994) Teori - Teori Sosial Budaya, Proyek Pembinaan Dan Peningkatan Mutu Tenaga Kependidikan. Direktorat Jenderal Pendidikan Tinggi Dan Kebudayaan.

Robbins, S. P. (2001) Organizational Behavior, 9th Ed. Upper Saddle River New Jersey: Prentice Hall International.

Spencer, L. M. and Spencer, S. M. (1993) Competence Work: Model for Superior Performance. New York: John Wiley and Sons, Inc.

Syah, M. (2000) Psikologi Pendidikan dengan Pendekatan Baru. Bandung: PT Remaja Rosdakarya. 